\title{
Greenhouse Gas Emissions after Application of Landfilled Paper Mill Sludge for Land Reclamation of a Nonacidic Mine Tailings Site
}

\author{
Patrick Faubert, * Simon Durocher, Normand Bertrand, Rock Ouimet, Philippe Rochette, Pascal Tremblay, \\ Jean-François Boucher, and Claude Villeneuve
}

\begin{abstract}
Large areas of mine tailings are reclaimed by applying organic amendments such as paper mill sludge (PMS). Although mining industries can use PMS freshly generated by paper mills, operational constraints on paper industries make temporary landfilling of this material an unavoidable alternative for the paper industries, creating the most prominent PMS source for mining industries. This study aimed to quantify soil greenhouse gas (GHG) emissions $\left(\mathrm{N}_{2} \mathrm{O}, \mathrm{CO}_{2}\right.$, and $\left.\mathrm{CH}_{4}\right)$ after application of landfilled PMS (LPMS; i.e., excavated from a landfill site at a paper mill) and LPMS combined with a seeding treatment of white clover (Trifolium repens $\mathrm{L}$.) on nonacidic mine tailings site prior to reforestation. Soil $\mathrm{N}_{2} \mathrm{O}, \mathrm{CO}_{2}$, and $\mathrm{CH}_{4}$ fluxes were measured after applications of 50 and $100 \mathrm{Mg}$ dry LPMS ha ${ }^{-1}$ during two consecutive snowfree seasons on two adjacent sites; LPMS was applied once in the first season. The LPMS application increased $\mathrm{N}_{2} \mathrm{O}$ emissions (7.6 to $34.7 \mathrm{~kg} \mathrm{~N}_{2} \mathrm{O}-\mathrm{N} \mathrm{ha}^{-1}$, comprising 1.04 to $2.43 \%$ of applied $\mathrm{N}$ ) compared with the unamended control during the first season; these emissions were negligible during the second season. The LPMS application increased $\mathrm{CO}_{2}$ emissions ( 5800 to $11,400 \mathrm{~kg}$ $\mathrm{CO}_{2}-\mathrm{C} \mathrm{ha}{ }^{-1}$, comprising 7 to $27 \%$ of applied C) compared with the unamended control on both sites and in both seasons. Fluxes of $\mathrm{CH}_{4}$ were negligible. White clover combined with LPMS treatments did not affect soil GHG emissions. These new GHG emission factors should be integrated into life-cycle analyses to evaluate the $C$ footprint of potential symbioses between the mining and paper industries. Future research should focus on the effect of PMS applications on soil GHG emissions from a variety of mine tailings under various management practices and climatic conditions to plan responsible and sustainable land reclamation.
\end{abstract}

\section{Core Ideas}

- Applied PMS for mine tailings reclamation affected GHG emissions.

- PMS application increased $\mathrm{N}_{2} \mathrm{O}$ and $\mathrm{CO}_{2}$ emissions, whereas $\mathrm{CH}_{4}$ fluxes were negligible.

-White clover combined with PMS treatments did not affect soil GHG emissions.

- Mine and paper industries can integrate these GHG emissions into industrial symbioses.

Copyright $\odot$ American Society of Agronomy, Crop Science Society of America, and Soil Science Society of America. 5585 Guilford Rd., Madison, WI 53711 USA. All rights reserved.

J. Environ. Qual. 46:950-960 (2017)

doi:10.2134/jeq2017.03.0119

This is an open access article distributed under the terms of the CC BY-NC-ND

license (http://creativecommons.org/licenses/by-nc-nd/4.0/)

Received 22 Mar. 2017.

Accepted 25 June 2017.

*Corresponding author (patrick1_faubert@uqac.ca).
$\mathrm{T}$ $\mathrm{HE}$ mining industry is responsible for restoring and reclaiming extensive areas of land degraded by the tailings produced by underground mining. Mine tailings can be reclaimed by importing topsoil, but this practice is often expensive. Alternatively, land can also be reclaimed using organic amendments such as paper mill sludge (PMS; Larney and Angers, 2012). Paper mill sludge is the main organic residue generated by wastewater treatments in the pulp and paper industry. Application of PMS on degraded lands has been shown to have positive impacts on several soil characteristics, such as organic matter content, microorganism activity, aggregate formation, water-holding capacity, and nutrient availability (Fierro et al., 1999; Piearce et al., 2003; Camberato et al., 2006; Shipitalo and Bonta, 2008; Larney and Angers, 2012; Faubert et al., 2016). Mining industries can use PMS freshly generated by pulp and paper mills, but operational constraints such as winter conditions, hauling distances, and the timing mismatch between PMS production (daily) and land application for reclamation purposes (yearly) make temporary landfilling of PMS both an unavoidable practice for pulp and paper industries and the most prominent PMS source for mining industries. In this industrial symbiosis, landfilled PMS (LPMS) from the pulp and paper industry becomes a valuable resource for the mining industry for the reclamation of mine tailings. However, greenhouse gas (GHG) emissions from LPMS (i.e., PMS excavated from a landfill site at a paper mill) applied to reclaim mine tailings are unknown (Larney and Angers, 2012). Therefore, a responsible PMS management plan regarding its global impact on climate change (Faubert et al., 2016) is needed, as both industries are subject to GHG inventories in the jurisdiction where the present study was conducted (the province of Quebec, Canada).

The land application of organic amendments modifies soil GHG fluxes (Thangarajan et al., 2013). Nitrous oxide $\left(\mathrm{N}_{2} \mathrm{O}\right)$ is mostly produced in amended soils by nitrification and denitrification processes (Thangarajan et al., 2013). Availabilities of $\mathrm{N}$

\footnotetext{
P. Faubert, S. Durocher, and C. Villeneuve, Chaire en éco-conseil, Dép. des sciences fondamentales, Univ. du Québec à Chicoutimi, 555 boulevard de I'Université, Chicoutimi, QC, Canada, G7H 2B1; N. Bertrand, and P. Rochette, Agriculture and Agri-Food Canada, Quebec Research and Development Centre, 2560 Hochelaga Blvd., Québec, QC, Canada, G1V 2J3; R. Ouimet, Ministère des Forêts, de la Faune et des Parcs, Direction de la recherche forestière, Complexe scientifique, 2700 Einstein St., Québec, QC, Canada, G1P 3W8; P. Tremblay and J.-F. Boucher, Dép. des sciences fondamentales, Univ. du Québec à Chicoutimi, 555 boulevard de l'Université, Chicoutimi, QC, Canada, G7H 2B1. P. Faubert and S. Durocher contributed equally to this work. Assigned to Associate Editor Claudia Wagner-Riddle.
}

Abbreviations: GHG, greenhouse gas; LPMS, landfilled paper mill sludge; LPMS-IEF, landfilled paper mill sludge-induced emission factor; PMS, paper mill sludge; S1, Site 1; S2, Site 2; VWC, volumetric water content. 
and $\mathrm{C}$ often control the rate of these reactions (Bouwman et al., 2002). In C-poor soils, denitrification is limited by $C$ availability (Chantigny et al., 2010; Pelster et al., 2012) and is usually stimulated by the addition of organic amendments (Loro et al., 1997; Mogge et al., 1999; Tenuta et al., 2000; Dambreville et al., 2006a, 2006b) such as PMS (Baggs et al., 2002; Chantigny et al., 2013). In contrast, lower emissions from soils receiving deinking PMS (C/ $\mathrm{N}$ ratios of 61-71) than from an unamended control have been attributed to soil $\mathrm{N}$ immobilization during amendment decomposition (Chantigny et al., 2013).

The decomposition of land-applied organic amendments increases carbon dioxide $\left(\mathrm{CO}_{2}\right)$ emissions from soils (Thangarajan et al., 2013). The large amounts of PMS-organic $\mathrm{C}$ are known to influence several active soil C pools (Chantigny et al., 1999) and to increase microbial biomass and activity rate (Chantigny et al., 2000). Although several examples are known, using a variety of methods, where organic amendments stimulate GHG emissions (Boeckx and Van Cleemput, 1996; Chantigny et al., 1999; Fierro et al., 2000; Rochette et al., 2000a; Thangarajan et al., 2013; Oliveira et al., 2017), there is no known report on the in situ monitoring of soil-surface $\mathrm{CO}_{2}$ emissions to assess the decomposition rate of PMS in reclaimed soils. Decomposition of organic matter at low redox potentials also produces methane $\left(\mathrm{CH}_{4}\right)$, large emissions of which have been reported after the addition of organic amendments to saturated soils (Boeckx and Van Cleemput, 1996). In contrast, disturbance of well-aerated soils has resulted in decreased oxidation of atmospheric $\mathrm{CH}_{4}$ by methanotrophs (Hansen et al., 1993). The addition of LPMS to C-poor mine tailings mixed with C-rich topsoil could therefore have positive or negative impacts on the contribution of $\mathrm{CH}_{4}$ net emissions to the soil GHG balance. However, no study has reported $\mathrm{CH}_{4}$ emissions relative to the application of LPMS on reclaimed and degraded soil such as nonacidic mine tailings (Larney and Angers, 2012; Faubert et al., 2016).

The Intergovernmental Panel on Climate Change (IPCC) ruled on a default emission factor of $1 \%$ of $\mathrm{N}$ added in the form of mineral or organic fertilizer on agricultural soils that is emitted as $\mathrm{N}_{2} \mathrm{O}-\mathrm{N}$ (Eggleston et al., 2006). No emission factor has been recommended so far for $\mathrm{N}$ applications on reclaimed lands to favor the establishment and growth of vegetation (Larney and Angers, 2012; Faubert et al., 2016). Policymakers, the mining industry, and the pulp and paper industry need to know LPMS-induced emission factors (LPMS-IEF), as there is a potential demand for LPMS amendments to reclaim mine tailings. For instance, in the province of Quebec, 12,000 ha of degraded lands (on 322 mine sites) potentially need to be restored and reclaimed after mining activities (MERN, 2017), creating a substantial demand for LPMS amendments. In this jurisdiction, $25 \%$ of the annual PMS production of $1.3 \mathrm{Tg}$ is currently landfilled; this practice will be banned by the provincial government by 2020 in favor of land application, which has been promoted as an alternative to landfilling (MDDEP, 2011; Gouvernement du Québec, 2012; MDDELCC, 2016). In this study, it is expected that LPMS application will increase $\mathrm{N}_{2} \mathrm{O}$ and $\mathrm{CO}_{2}$ emissions as a consequence of the increased mineral $\mathrm{N}$ $\left(\mathrm{NO}_{3}\right.$ and $\left.\mathrm{NH}_{4}\right)$ and $\mathrm{C}$ availability, favoring denitrification, nitrification, and soil respiration in the C-poor study soil (Chantigny et al., 2010; Pelster et al., 2012; Oliveira et al., 2017). The $\mathrm{CH}_{4}$ emissions are expected to be negligible after LPMS application on this well-drained soil (Le Mer and Roger, 2001; Thangarajan et al., 2013), possibly favoring methanotrophy.
This study aimed (i) to quantify the soil GHG emissions $\left(\mathrm{N}_{2} \mathrm{O}, \mathrm{CO}_{2}\right.$, and $\left.\mathrm{CH}_{4}\right)$ after a single application of LPMS and LPMS combined with a seeding treatment of white clover (Trifolium repens L.) on a nonacidic mine tailings site prior to reforestation during two consecutive snow-free seasons on two adjacent sites, and (ii) to provide field-measured LPMS-IEFs, which could decrease the uncertainty related to the GHG emissions associated with this practice (Larney and Angers, 2012; Faubert et al., 2016). White clover was selected because it is used as a perennial soil cover for site preparation prior to reclamation by reforestation on these tailings.

\section{Materials and Methods}

\section{Study Site and Experimental Design}

The study was conducted on a nonacidic tailings impoundment facility located on a private underground mine property (Niobec, Saint-Honoré, QC, Canada; $48^{\circ} 32^{\prime} \mathrm{N}, 71^{\circ} 08^{\prime} \mathrm{W}$ ). Mining activities started in 1975, and the mine tailings site has a total area of $62 \mathrm{ha}$. The area on which the tailings site was installed at the beginning of mining activities was first prepared by harvesting trees and removing the forest floor, which was stored on the mine site. Once a tailings area had reached its full height capacity, the forest floor removed in the past was used to cover the surface to limit spreading of the tailings particles in the surrounding environment through wind dispersion. Although forest floor materials covered the tailings, a natural mixing occurred over time with tailings from neighboring active sites. Thus, the soil is classified as a Technosol (IUSS Working Group, 2015) made from calcareous tailings $(150-180 \mu \mathrm{m})$ covered and naturally mixed with endemic forest floor (Table 1 ).

The experimental sites were installed on a portion of the tailings site that was previously plowed with a rotary tiller (0- to 20 -cm depth). The portion was divided into two adjacent experimental sites ( $\mathrm{S} 1$ and S2), each covering a $625-\mathrm{m}^{2}$ area. The experimental design on each site included three LPMS treatments

Table 1. Physical and chemical characteristics of the nonacidic mine tailings on the experimental sites ( $\mathrm{S} 1$ and $\mathrm{S} 2$, top $30 \mathrm{~cm}$ ) and landfilled paper mill sludge (LPMS) applied during the first year of the experiment.

\begin{tabular}{lcrr}
\hline \multirow{2}{*}{ Parameter† } & Tailings & \multicolumn{2}{c}{ LPMS } \\
\cline { 3 - 4 } & & \multicolumn{1}{c}{$\mathrm{S} 1$} & $\mathrm{~S} 2$ \\
\hline Total C $\left(\mathrm{g} \mathrm{kg}^{-1}\right)$ & 95.3 & 350 & 140 \\
Organic C $\left(\mathrm{g} \mathrm{kg}^{-1}\right)$ & 33.4 & 350 & 140 \\
Total N $\left(\mathrm{g} \mathrm{kg}^{-1}\right)$ & 1.01 & 15 & 7.5 \\
$\mathrm{NH}_{4}-\mathrm{N}\left(\mathrm{mg} \mathrm{kg}^{-1}\right)$ & 1.7 & 5,300 & 740 \\
$\mathrm{NO}_{3}-\mathrm{N}\left(\mathrm{mg} \mathrm{kg}^{-1}\right)$ & 3.4 & 40 & 40 \\
$\mathrm{C} / \mathrm{N}$ & 94.5 & 23.3 & 18.7 \\
$\mathrm{pH}$ & 7.78 & 7.64 & 8.12 \\
$\mathrm{P}(\mathrm{mg} \mathrm{kg}$ & $-1)$ & 2,182 & 1,600 \\
$\mathrm{~K}\left(\mathrm{mg} \mathrm{kg}^{-1}\right)$ & 3.7 & 830 & 700 \\
$\mathrm{Ca}\left(\mathrm{mg} \mathrm{kg}^{-1}\right)$ & 43 & 5,000 & 14,000 \\
$\mathrm{Mg}\left(\mathrm{mg} \mathrm{kg}^{-1}\right)$ & 4,308 & 0 & 2,700 \\
Sand $(\%)$ & 147 & nd & nd \\
Silt $(\%)$ & 88 & nd & nd \\
Clay $(\%)$ & 7 & nd & nd \\
\hline
\end{tabular}

†All values are expressed on a dry matter basis; nd, not determined; $\mathrm{NO}_{3}-\mathrm{N}$ is the concentration of $\left(\mathrm{NO}_{2}+\mathrm{NO}_{3}\right)-\mathrm{N}$ for the tailings.

₹ Mixture of calcareous tailings covered and naturally mixed with endemic forest floor for S1 and S2. 
and two seeding treatments of white clover, replicated in three blocks and organized in a full factorial randomized complete block design with 18 experimental plots $(2 \times 2 \mathrm{~m}$ each $)$ per site. The LPMS treatments consisted of targeted application rates of 0 , 50, or $100 \mathrm{Mg}$ dry LPMS ha ${ }^{-1}$ (Table 2). The seeding treatments of white clover consisted of absence and presence at rates of 0 and $12 \mathrm{~kg} \mathrm{ha}^{-1}$, respectively. This plant species was selected prior to reclamation of the site on these tailings for the following reasons: (i) to limit dust transport by wind, (ii) to control the competition of other undesired plant species, (iii) to avoid light competition with tree seedlings for reforestation due clover's low height, and (iv) to fix atmospheric $\mathrm{N}_{2}$ in the soil through clover's root nodules. Buffer strips of 2.5 and $5 \mathrm{~m}$ were inserted between each plot and block, respectively.

The LPMS was excavated from a landfill site at a nearby $(25.9 \mathrm{~km})$ paper mill (Resolute Forest Products, Jonquière, QC, Canada; $48^{\circ} 25^{\prime} \mathrm{N}, 71^{\circ} 14^{\prime} \mathrm{W}$ ). The $\mathrm{S} 1$ was set up on 9 to $10 \mathrm{July}$ 2012 and used excavated LPMS transported to the site on 5 July 2012. The S2 was established on 4 to 5 July 2013 and used excavated LPMS that was transported to the site on 4 July 2013. On both sites, the LPMS was manually incorporated into the soil at a 10-cm depth, using a digging fork and a hand rake for surface leveling, to mimic the operational application of LPMS during reclamation on this site. White clover was seeded by hand on 17 July 2012 and 9 July 2013 for S1 and S2, respectively.

\section{LPMS Characteristics}

The LPMS consisted of mixed primary and secondary sludge generated from thermomechanical pulp and paper manufacturing processes and landfilled for $\sim 1$ yr (Tables 1 and 2). The excavated sludge was sampled (composite subsampling) for characterization on 6 July 2012 (S1) and 5 July 2013 (S2). Dry matter content was measured by oven drying at $105^{\circ} \mathrm{C}$ to a constant weight (Sheppard and Addison, 2008). The mineral $\mathrm{N}$ concentration was measured by extraction with $2 \mathrm{~mol} \mathrm{~L}^{-1} \mathrm{KCl}$ (1:10, ratio LPMS:extractant) followed by filtration (Maynard et al., 2008). Total $\mathrm{N}$ content was determined after a Kjeldahl digestion (Rutherford et al., 2008). The $\mathrm{N}$ concentration in the extracts was measured by an automated colorimeter (S1: Technicon Autoanalyzer II, Technicon Instruments Corporation; S2: Konelab Aqua 20, Thermo Fisher Scientific). For LPMS used on S1, the total C content was measured by loss on ignition at $485^{\circ} \mathrm{C}$ for a minimum of $12 \mathrm{~h}$ (conversion factor from organic matter to total $\mathrm{C}$ of 0.5 ; Giroux and Audesse, 2004). For LPMS used on S2, total C was determined by dry combustion (Skjemstad and Baldock, 2008; LECO C230 Carbon Analyzer, LECO Corporation).

\section{Gas Flux Measurement}

Experimental designs $S 1$ and $S 2$ were monitored during two consecutive snow-free seasons after LPMS application (S1: 5 July to 23 Oct. 2012 and 23 Apr. to 24 Oct. 2013; S2: 4 July to 23 Oct. 2013 and 30 Apr. to 6 Oct. 2014). Soil-surface $\mathrm{N}_{2} \mathrm{O}$, $\mathrm{CO}_{2}$, and $\mathrm{CH}_{4}$ fluxes were measured simultaneously using non-flow-through non-steady-state chambers (Rochette and Bertrand, 2008) during the first season as follows: thrice a week for the first month after LPMS application, twice a week for the second month, and weekly throughout the remaining season. During the second season, the sampling frequency was decreased and fluxes were measured after snow melt until late October. Systematic sampling was performed up to twice a week from April until mid-May, up to once every second week from mid-May until late June, and monthly until late October, for a total of 15 sampling days throughout the second season in 2013 (S1) and 11 sampling days in 2014 (S2). Acrylic enclosures were composed of a permanent frame $(0.75 \times 0.15 \times 0.14 \mathrm{~m}$ high $)$ inserted at the center of each plot to a $0.1-\mathrm{m}$ depth, and a removable chamber $(0.75 \times 0.15 \times 0.15 \mathrm{~m}$ high $)$ was sealed to the frame at the time of measurement. The height of frames above the soil surface was measured on each sampling date for the first month, then after precipitation events for the remainder of the season. The frames were accessed from the same direction in the plot, and a wood board was placed on the soil surface during GHG measurements to avoid soil compaction around the chamber caused by repeated walking. The air in the chamber headspace was sampled $(20 \mathrm{~mL})$ at $0,6,12$, and $18 \mathrm{~min}$ after chamber deployment with a syringe through a rubber septum, and the sample was transferred immediately to pre-evacuated 12 -mL glass vials (Exetainer, Labco). Gas samples, along with known standards, were analyzed within $15 \mathrm{~d}$ of collection using a gas chromatograph (Bruker, model 450) with $\mathrm{Ar} / \mathrm{CH}_{4}(95 / 5)$ carrier gas through a 1.75 -m-long Porapak Q $80 / 100$ column $\left(60^{\circ} \mathrm{C}\right)$ equipped with an electron capture detector for $\mathrm{N}_{2} \mathrm{O}$, and with $\mathrm{He}$ carrier gas through a 3.6-m-long Hayesep A 80/100 column equipped with a flame ionization detector for $\mathrm{CH}_{4}$, and for $\mathrm{CO}_{2}$ after passing through a methanizer (catalyst column, Ni Nitrate $10 \%, 400^{\circ} \mathrm{C}$ ). Soil $\mathrm{N}_{2} \mathrm{O}, \mathrm{CO}_{2}$, and $\mathrm{CH}_{4}$ fluxes were calculated using equations proposed by Rochette and Bertrand (2008), in which the rate of change of chamber GHG concentration was estimated using linear or nonlinear methods. The GHG fluxes were considered greater than zero (i.e., minimum detectable flux) when changes in gas concentrations during deployment were above the analytical variability levels $\left(\mathrm{N}_{2} \mathrm{O}: 0.005 \mu \mathrm{mol} \mathrm{mol}{ }^{-1} ; \mathrm{CH}_{4}: 0.05 \mu \mathrm{mol}\right.$

Table 2. Mean ( $\pm S D, n=6$ ) chemical characteristics of the applications of landfilled paper mill sludge (LPMS) on two experimental sites (S1 and S2) for the first year of the experiment on nonacidic mine tailings.

\begin{tabular}{|c|c|c|c|c|}
\hline Targeted LPMS rate $\dagger$ & Applied LPMS rate & Total N & $\mathrm{NH}_{4}-\mathrm{N}$ & Total C \\
\hline \multicolumn{5}{|l|}{ S1 } \\
\hline 50 & $47.3 \pm 0.01$ & $0.709 \pm 0.0002$ & $0.251 \pm 0.0001$ & $16.52 \pm 0.004$ \\
\hline 100 & $94.5 \pm 0.02$ & $1.418 \pm 0.0003$ & $0.501 \pm 0.0001$ & $33.03 \pm 0.008$ \\
\hline \multicolumn{5}{|l|}{ S2 } \\
\hline 50 & $68.0 \pm 0.05$ & $0.510 \pm 0.0004$ & $0.050 \pm 0.00004$ & $9.52 \pm 0.007$ \\
\hline 100 & $135.9 \pm 0.05$ & $1.020 \pm 0.0004$ & $0.101 \pm 0.00004$ & $19.03 \pm 0.008$ \\
\hline
\end{tabular}

†Application rates are expressed on a dry-matter basis.

₹ As applied on the day of application based on the dry matter content. 
$\left.\mathrm{mol}^{-1} ; \mathrm{CO}_{2}: 1 \mu \mathrm{mol} \mathrm{mol}{ }^{-1}\right)$. Vegetation inside gas measurement frames was removed by hand on each sampling date, but it was left undisturbed on the remaining part of each plot. Removal was necessary to measure solely soil GHG emissions and eliminate the effect of $\mathrm{C}$ and $\mathrm{N}$ mineralization by plants on the measurement surface. The effect of white clover on soil GHG fluxes was determined indirectly.

Cumulative area-based $\mathrm{N}_{2} \mathrm{O}, \mathrm{CO}_{2}$, and $\mathrm{CH}_{4}$ emissions were calculated for the snow-free season using numerical integration and following the assumption that changes between sampling dates were linear (Chantigny et al., 2013; de Klein and Harvey, 2015). The LPMS-IEFs were calculated by subtracting cumulative gaseous emissions from 0-Mg LPMS ha-1 plots from the cumulative gaseous emissions of 50- and 100-Mg LPMS ha-1 plots and dividing by the total amount of $\mathrm{N}$ or $\mathrm{C}$ applied during the first season.

\section{Soil Sampling and Analyses}

Soil samples were collected in 2013 during the first year of the experiment on S2 plots. Soil mineral $\mathrm{N}\left[\left(\mathrm{NO}_{2}+\mathrm{NO}_{3}\right)-\mathrm{N}\right.$ and $\mathrm{NH}_{4}-\mathrm{N}$ ] was analyzed at regular intervals. Samples were taken weekly before and after LPMS application ( 4 and 11 July, respectively) for a month $(18,25$, and 30 July and 6 August) and then monthly for the rest of the snow-free season (12 Aug., 18 Sept., and 21 Oct. 2013). Four soil cores were taken from the top $30 \mathrm{~cm}$ using a stainless steel probe sampler (2-cm diam.). Composite samples were made for each plot and stored in a plastic bag at $4^{\circ} \mathrm{C}$ within $4 \mathrm{~h}$. The extraction was performed within $24 \mathrm{~h}$ with $1 \mathrm{~mol} \mathrm{~L}^{-1} \mathrm{KCl}$ (1:5, soil:extractant ratio). The soil-solution mixture was agitated on a reciprocal shaker for $1 \mathrm{~h}$, followed by centrifugation at $3000 \mathrm{~g}$ for $10 \mathrm{~min}$. The supernatant was filtered using Whatman \#42 papers prewashed with $1 \mathrm{~mol} \mathrm{~L}{ }^{-1} \mathrm{KCl}$. The extracts were stored at $-18^{\circ} \mathrm{C}$ until analysis for $\left(\mathrm{NO}_{2}+\mathrm{NO}_{3}\right)-\mathrm{N}$ and $\mathrm{NH}_{4}-\mathrm{N}$ concentrations by an automated colorimeter (Model QuickChem 8000 FIA+, Lachat Instruments). The soil $\mathrm{NO}_{2}+\mathrm{NO}_{3}$ and $\mathrm{NH}_{4}$ exposures, which are integrated measures of the daily exposure of soil microorganisms to $\mathrm{NO}_{2}+\mathrm{NO}_{3}$ and $\mathrm{NH}_{4}$ over time, were calculated for the snow-free season using numerical integration and following the assumption that changes between sampling dates were linear (Burton et al., 2008). On each gas sampling date, soil volumetric water content (VWC) at 20-cm depth was also measured using a portable time domain reflectometry meter (TDR 100, Fieldscout, Spectrum Technologies). Precipitation was monitored at the Environment and Climate Change Canada weather station at St-Ambroise, QC, located $17 \mathrm{~km}$ from the experimental site $\left(48^{\circ} 34^{\prime} \mathrm{N}, 71^{\circ} 20^{\prime} \mathrm{W}\right)$.

\section{Statistical Analyses}

Statistical analyses were performed using JMP Pro (SAS Institute, 2015). The treatment effects on the cumulative areabased $\mathrm{N}_{2} \mathrm{O}, \mathrm{CO}_{2}$, and $\mathrm{CH}_{4}$ emissions were tested separately for each site (S1 and S2) and snow-free season (2012: S1 [Year 1]; 2013: S1 [Year 2], S2 [Year 1]; 2014: S2 [Year 2]) using linear mixed model ANOVA. The experimental plan modeled was a randomized complete block design, with LPMS rate and seeding treatments and their interactions as fixed factors and block as a random factor. Linear and quadratic contrasts (single degree of freedom, a priori comparisons) were used to test treatment effects when the fixed factors and their interactions resulted in significant differences between the treatments. The same linear mixed model was used to test the treatment effects on the soil $\mathrm{NO}_{2}+\mathrm{NO}_{3}$ and $\mathrm{NH}_{4}$ exposures (2013: S2 [Year 1]). Data were $\log _{10}$-transformed when necessary to comply with assumption of homogeneity of variances. Spearman's nonparametric correlation coefficients $(\rho)$ were used to test the relationships between soil VWC and soil-surface $\mathrm{N}_{2} \mathrm{O}$ and $\mathrm{CO}_{2}$ fluxes. Spearman's correlations were also performed to test the relationships between cumulative area-based $\mathrm{N}_{2} \mathrm{O}$ emissions and soil $\mathrm{NO}_{2}+\mathrm{NO}_{3}$ and $\mathrm{NH}_{4}$ exposures.

\section{Results}

\section{Soil-Surface $\mathrm{N}_{2} \mathrm{O}$ Emissions}

Soil-surface $\mathrm{N}_{2} \mathrm{O}$ fluxes were relatively low in control plots $\left(0 \mathrm{Mg} \mathrm{LPMS} \mathrm{ha}^{-1}\right)$ throughout the first season of the experiment on both sites ( $<0.13 \mathrm{mg} \mathrm{N}_{2} \mathrm{O}-\mathrm{N} \mathrm{m}^{-2} \mathrm{~h}^{-1}$, Fig. 1a). On LPMSamended plots, fluxes peaked after 7 and $6 \mathrm{~d}$ following application, reaching values up to 24.2 and $10.6 \mathrm{mg} \mathrm{N}_{2} \mathrm{O}-\mathrm{N} \mathrm{m}^{-2} \mathrm{~h}^{-1}$ on $\mathrm{S} 1$ and $\mathrm{S} 2$, respectively. On both sites, fluxes from amended plots gradually decreased to the level of unamended control during the $40 \mathrm{~d}$ after LPMS application and remained at this level for the remainder of the season (Fig. 1a). There was a significant correlation between soil VWC and soil-surface $\mathrm{N}_{2} \mathrm{O}$ fluxes (Spearman's $\rho=0.2367, p<0.0001$ ) on S1 during the first season after application; no correlation was observed on S2. On S1, peaks in the fluxes coincided with a short period of rainfall reaching up to $28 \mathrm{~mm}$ (13 July 2012), whereas no such high rainfalls occurred during the peak period on S2 (Fig. 1c). Rainfall events did not seem to affect $\mathrm{N}_{2} \mathrm{O}$ fluxes after the 4-wk peak period following LPMS application during the first season on both sites.

Landfilled PMS application significantly increased the cumulative area-based $\mathrm{N}_{2} \mathrm{O}$ emissions at both sites during the first season (Tables 3 and 4). Cumulative area-based $\mathrm{N}_{2} \mathrm{O}$ emissions from LPMS-amended plots varied from 7.56 to $34.7 \mathrm{~kg} \mathrm{~N} \mathrm{~N}_{2} \mathrm{O}-\mathrm{N}$ $\mathrm{ha}^{-1}$ during the first season after application and were 23 to 297 times greater than values from control plots, which ranged between 0.117 and $0.331 \mathrm{~kg} \mathrm{~N}_{2} \mathrm{O}-\mathrm{N} \mathrm{ha}^{-1}$ (Table 3). Cumulative $\mathrm{N}_{2} \mathrm{O}$ emissions were 2.2 to 4.6 times higher for plots receiving $100 \mathrm{Mg}$ LPMS ha- ${ }^{-1}$ than for plots receiving $50 \mathrm{Mg} \mathrm{LPMS} \mathrm{ha}^{-1}$ on both sites (Table 3). Nitrous oxide losses were negligible during the second season after LPMS application (Table 3). On S1 during the second season, LPMS had no significant effect on the cumulative $\mathrm{N}_{2} \mathrm{O}$ emissions while the effect was significant on S2, although the absolute values were still within the range of very low values for Year 2 on each site and a clear trend was not obvious from the data (Tables 3 and 4). On both sites and seasons, the presence of $T$. repens had no significant effect on cumulative $\mathrm{N}_{2} \mathrm{O}$ emissions (Tables 3 and 4). The LPMS-IEFs ranged from 0.0104 to $0.0243 \mathrm{~kg} \mathrm{~N}_{2} \mathrm{O}-\mathrm{N} \mathrm{kg}^{-1} \mathrm{~N}$ applied during the first season (highest LPMS-IEF measured for $100 \mathrm{Mg}$ LPMS $\mathrm{ha}^{-1}$ ) and were negligible during the second season (Table 3). The correlations between cumulative area-based $\mathrm{N}_{2} \mathrm{O}$ emissions and soil $\mathrm{NO}_{2}+\mathrm{NO}_{3}$ and $\mathrm{NH}_{4}$ exposures were significant on $\mathrm{S} 2$ during the first season $\left(\mathrm{N}_{2} \mathrm{O}\right.$ emissions vs. $\mathrm{NO}_{2}+\mathrm{NO}_{3}$ exposure: Spearman's $\rho=0.8989, p<0.0001 ; \mathrm{N}_{2} \mathrm{O}$ emissions vs. $\mathrm{NH}_{4}$ exposure: Spearman's $\rho=0.8535, p<0.0001$ ). 
S1 - Year 1

S2 - Year 1

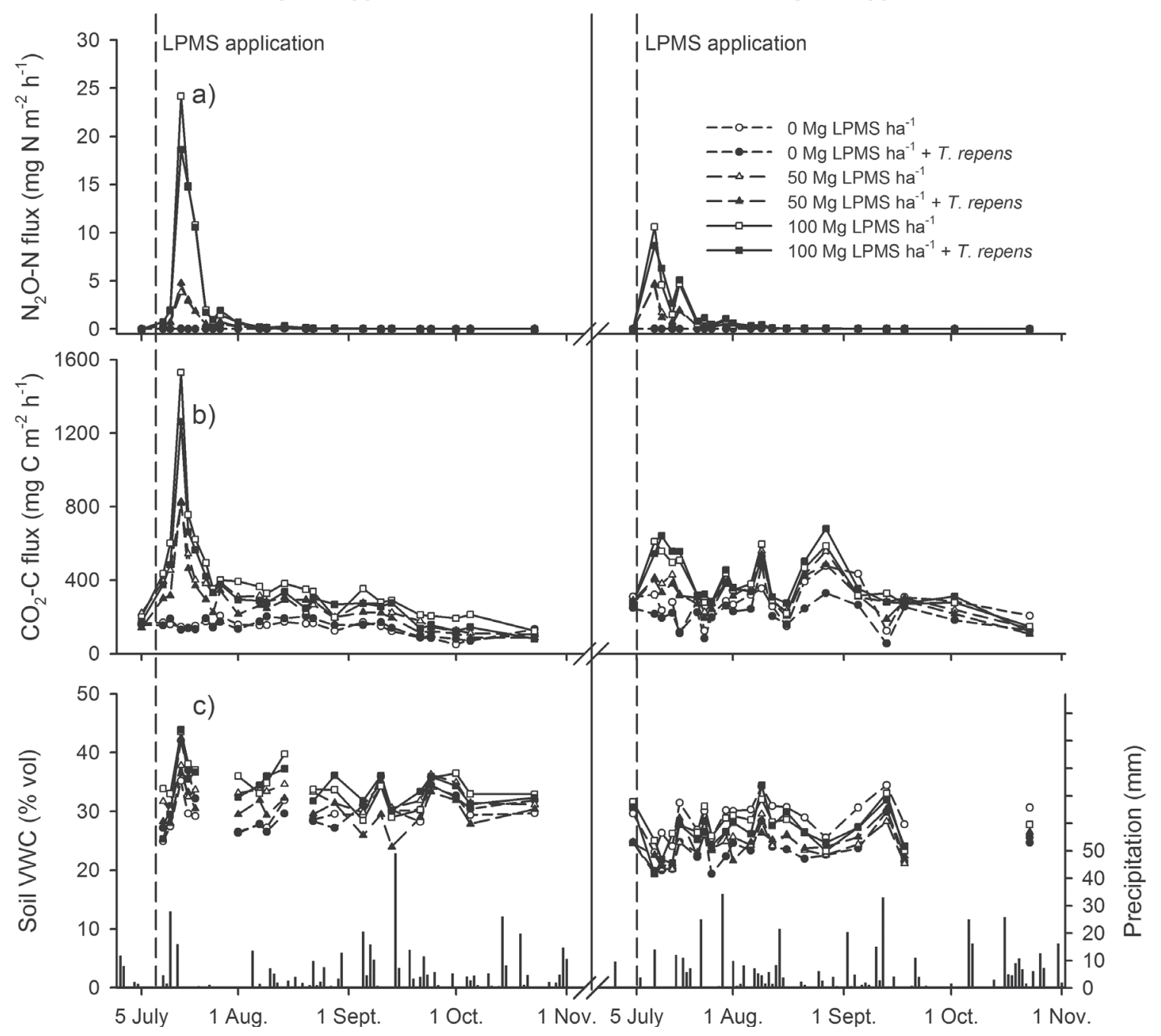

Fig. 1. Mean daily area-based (a) $\mathrm{N}_{2} \mathrm{O}$, (b) $\mathrm{CO}_{2}$ fluxes, and (c) soil volumetric water content (VWC) and precipitation after the applications of landfilled paper mill sludge (LPMS) combined with a seeding of white clover (Trifolium repens) on two experimental sites (S1 and S2) during the first snow-free seasons (Year 1 ) of the experiment on nonacidic mine tailings. The LPMS application rates were of 0,50 , and $100 \mathrm{Mg}^{\mathrm{dry}} \mathrm{LPMS}^{-1}$, and seeding rates of white clover were of 0 and $12 \mathrm{~kg} \mathrm{ha}^{-1}(n=3)$. Vertical dashed lines indicate LPMS application dates.

Table 3. Mean cumulative ( $\left(\mathrm{SD}, \boldsymbol{n}=3\right.$ ) area-based $\mathrm{N}_{2} \mathrm{O}$ emissions and induced emission factors (IEF) after the applications of landfilled paper mill sludge (LPMS) combined with a seeding of white clover (Trifolium repens) on two experimental sites (S1 and S2) and during two snow-free seasons (Years 1 and 2, LPMS applied in Year 1) on nonacidic mine tailings.

\begin{tabular}{|c|c|c|c|c|c|c|}
\hline \multirow{2}{*}{ Site } & \multirow{2}{*}{ Clover } & \multirow{2}{*}{$\begin{array}{l}\text { LPMS application } \\
\text { rate }\end{array}$} & \multicolumn{2}{|c|}{ Year 1} & \multicolumn{2}{|c|}{ Year 2} \\
\hline & & & Area-based $\mathrm{N}_{2} \mathrm{O}$ emissions & LPMS-IEF & Area-based $\mathrm{N}_{2} \mathrm{O}$ emissions & LPMS-IEF \\
\hline & & Mg dry LPMS ha-1 & $\mathrm{kg} \mathrm{N}_{2} \mathrm{O}-\mathrm{N} \mathrm{ha}^{-1}$ & $\mathrm{~kg} \mathrm{~N}_{2} \mathrm{O}-\mathrm{N} \mathrm{kg}^{-1} \mathrm{~N}$ & $\mathrm{~kg} \mathrm{~N}_{2} \mathrm{O}-\mathrm{N} \mathrm{ha}^{-1}$ & $\mathrm{~kg} \mathrm{~N}_{2} \mathrm{O}-\mathrm{N} \mathrm{kg}^{-1} \mathrm{~N}$ \\
\hline \multirow[t]{6}{*}{1} & Absence & 0 & $0.216 \pm 0.099$ & - & $0.0937 \pm 0.0573$ & - \\
\hline & & 50 & $7.56 \pm 2.45$ & $0.0104 \pm 0.0035$ & $0.159 \pm 0.071$ & $9.25 \times 10^{-5} \pm 1.2 \times 10^{-4}$ \\
\hline & & 100 & $34.7 \pm 11.6$ & $0.0243 \pm 0.0082$ & $0.127 \pm 0.148$ & $2.32 \times 10^{-5} \pm 1.3 \times 10^{-4}$ \\
\hline & Presence & 0 & $0.117 \pm 0.029$ & - & $0.0576 \pm 0.026$ & - \\
\hline & & 50 & $7.87 \pm 0.105$ & $0.0109 \pm 0.0001$ & $0.305 \pm 0.427$ & $3.49 \times 10^{-4} \pm 5.66 \times 10^{-4}$ \\
\hline & & 100 & $31.6 \pm 7.44$ & $0.0222 \pm 0.0052$ & $0.114 \pm 0.130$ & $3.99 \times 10^{-5} \pm 8.09 \times 10^{-5}$ \\
\hline \multirow[t]{6}{*}{2} & Absence & 0 & $0.217 \pm 0.101$ & - & $0.231 \pm 0.075$ & - \\
\hline & & 50 & $9.35 \pm 0.285$ & $0.0179 \pm 0.0007$ & $0.0762 \pm 0.0936$ & $-3.03 \times 10^{-4} \pm 3.31 \times 10^{-4}$ \\
\hline & & 100 & $20.8 \pm 4.2$ & $0.0202 \pm 0.0040$ & $0.0118 \pm 0.0074$ & $-2.15 \times 10^{-4} \pm 6.83 \times 10^{-5}$ \\
\hline & Presence & 0 & $0.331 \pm 0.257$ & - & $0.0864 \pm 0.0733$ & - \\
\hline & & 50 & $8.73 \pm 1.37$ & $0.0165 \pm 0.0031$ & $0.100 \pm 0.044$ & $2.71 \times 10^{-5} \pm 2.11 \times 10^{-4}$ \\
\hline & & 100 & $22.0 \pm 1.84$ & $0.0213 \pm 0.0019$ & $0.0886 \pm 0.0822$ & $2.08 \times 10^{-6} \pm 1.32 \times 10^{-4}$ \\
\hline
\end{tabular}


Table 4. The $P$ values of the ANOVA testing the effects of the applications of landfilled paper mill sludge (LPMS) combined with a seeding of white clover (Trifolium repens) on the cumulative area-based $\mathrm{N}_{2} \mathrm{O}, \mathrm{CO}_{2}$, and $\mathrm{CH}_{4}$ emissions on two experimental sites ( $\mathrm{S} 1$ and $\mathrm{S} 2$ ) and during two snow-free seasons (Years 1 and 2, LPMS applied in Year 1) on nonacidic mine tailings. Differences were considered statistically significant at $P<0.05$. Linear (Lin) and quadratic (Quad) contrasts were performed when the fixed factors, and their interactions resulted in significant differences between the treatments.

\begin{tabular}{|c|c|c|c|c|c|c|c|}
\hline \multirow{2}{*}{ Site } & \multirow{2}{*}{ Year } & \multirow{2}{*}{ Source } & \multirow{2}{*}{ Numerator df } & \multirow{2}{*}{ Denominator df } & \multicolumn{3}{|c|}{$P$ value } \\
\hline & & & & & $\mathrm{N}_{2} \mathrm{O}$ & $\mathrm{CO}_{2}$ & $\mathrm{CH}_{4}$ \\
\hline \multirow[t]{5}{*}{1} & 1 & LPMS & 2 & 10 & $<0.0001$ & $<0.0001$ & 0.5050 \\
\hline & & Lin & 1 & 10 & $<0.0001$ & $<0.0001$ & - \\
\hline & & Quad & 1 & 10 & $<0.0001$ & 0.0176 & - \\
\hline & & Clover & 1 & 10 & 0.2483 & 0.1152 & 0.3953 \\
\hline & & LPMS $\times$ Clover & 2 & 10 & 0.2558 & 0.1204 & 0.9803 \\
\hline \multirow[t]{7}{*}{1} & 2 & LPMS & 2 & 10 & 0.5104 & 0.0043 & 0.0705 \\
\hline & & Lin & 1 & 10 & - & 0.0018 & - \\
\hline & & Quad & 1 & 10 & - & 0.2059 & - \\
\hline & & Clover & 1 & 10 & 0.7091 & 0.1770 & 0.9487 \\
\hline & & LPMS $\times$ Clover & 2 & 10 & 0.9370 & 0.2229 & 0.0347 \\
\hline & & Lin & 1 & 10 & - & - & 0.0209 \\
\hline & & Quad & 1 & 10 & - & - & 0.1794 \\
\hline \multirow[t]{5}{*}{2} & 1 & LPMS & 2 & 10 & $<0.0001$ & 0.0045 & 0.0876 \\
\hline & & Lin & 1 & 10 & $<0.0001$ & 0.0013 & - \\
\hline & & Quad & 1 & 10 & $<0.0001$ & 0.9843 & - \\
\hline & & Clover & 1 & 10 & 0.6989 & 0.1830 & 0.6250 \\
\hline & & LPMS $\times$ Clover & 2 & 10 & 0.6868 & 0.2303 & 0.6419 \\
\hline \multirow[t]{5}{*}{2} & 2 & LPMS & 2 & 10 & 0.0499 & 0.0040 & 0.1357 \\
\hline & & Lin & 1 & 10 & 0.0173 & 0.0011 & - \\
\hline & & Quad & 1 & 10 & 0.7449 & 0.9450 & - \\
\hline & & Clover & 1 & 10 & 0.3460 & 0.3285 & 0.7337 \\
\hline & & LPMS $\times$ Clover & 2 & 10 & 0.0564 & 0.8735 & 0.5022 \\
\hline
\end{tabular}

\section{Soil-Surface $\mathrm{CO}_{2}$ Emissions}

Soil-surface $\mathrm{CO}_{2}$ fluxes in control plots were $<480 \mathrm{mg}$ $\mathrm{CO}_{2}-\mathrm{C} \mathrm{m}^{-2} \mathrm{~h}^{-1}$ on both sites throughout the first season of the experiment period (Fig. 1b). Fluxes from LPMS-amended plots reached values up to 1531 and $681 \mathrm{mg} \mathrm{CO}_{2}-\mathrm{C} \mathrm{m}^{-2} \mathrm{~h}^{-1}$ on $\mathrm{S} 1$ and $\mathrm{S} 2$, respectively. On $\mathrm{S} 1, \mathrm{CO}_{2}$ fluxes reached a peak $7 \mathrm{~d}$ after LPMS application and returned to near-background levels at the end of the first season. On S2, large fluxes were sporadically observed on control and amended plots (i.e., at Days 8, 26, 36, and 54; Fig. 1b). There was a significant correlation between soil VWC and CO fluxes on S1 (Spearman's $\rho=0.2164, p<0.0001$ ) during the first season after application, whereas this correlation was not observed on $S 2$.

The LPMS application significantly increased the cumulative area-based $\mathrm{CO}_{2}$ emissions on both sites during both seasons, whereas white clover did not have significant effects (Tables 4 and 5). Cumulative $\mathrm{CO}_{2}$ emissions ranged from 5784 to 11,423 $\mathrm{kg} \mathrm{CO}_{2}-\mathrm{C} \mathrm{ha}^{-1}$ on amended plots and from 3481 to $7635 \mathrm{~kg}$ $\mathrm{CO}_{2}-\mathrm{C}$ ha $^{-1}$ on control plots. Cumulative $\mathrm{CO}_{2}$ emissions were 1.05 to 1.31 times higher for plots receiving $100 \mathrm{Mg} \mathrm{LPMS} \mathrm{ha}{ }^{-1}$ than for plots receiving $50 \mathrm{Mg}$ LPMS ha-1 (Table 5). On both sites, LPMS-IEFs ranged from 0.0787 to 0.222 and 0.0715 to $0.272 \mathrm{~kg} \mathrm{CO}_{2}-\mathrm{C} \mathrm{kg}^{-1} \mathrm{C}$ applied for the first and second years after application, respectively (Table 5).

\section{Soil-Surface $\mathrm{CH}_{4}$ Fluxes}

The cumulative area-based $\mathrm{CH}_{4}$ fluxes were mainly negative at both sites and for both seasons from LPMS-amended and unamended control plots, ranging from -0.413 to $-0.0121 \mathrm{~kg}$ $\mathrm{CH}_{4}-\mathrm{C} \mathrm{ha}^{-1}$ (data not shown), which may have been a slight uptake as it is considered negligible in terms of contribution to overall GHG emissions. On S1, a significant interaction was observed between LPMS and T. repens treatments on the second year after LPMS application (Table 4), but values obtained were again considered negligible (data not shown).

\section{Soil Mineral N Concentrations}

During the first season on $\mathrm{S} 2$, the soil $\left(\mathrm{NO}_{2}+\mathrm{NO}_{3}\right)-\mathrm{N}$ concentrations increased gradually after LPMS application until a peak was reached on Day 33; near-background levels were reached at the end of the season (109 d, Fig. 2a). The soil $\mathrm{NH}_{4}-\mathrm{N}$ concentrations peaked $1 \mathrm{wk}$ after land application and returned to nearbackground levels after $39 \mathrm{~d}$ (Fig. 2b). The LPMS application significantly increased the soil $\mathrm{NO}_{2}+\mathrm{NO}_{3}$ and $\mathrm{NH}_{4}$ exposures, whereas T. repens treatments had no effect (Table 6).

\section{Discussion}

\section{Soil-Surface $\mathrm{N}_{2} 0$ Emissions}

Cumulative area-based $\mathrm{N}_{2} \mathrm{O}$ emissions on control plots after one growing season ( 0.117 to $0.331 \mathrm{~kg} \mathrm{~N}_{2} \mathrm{O}-\mathrm{N} \mathrm{ha}^{-1}$ ) were lower than documented average emissions for unamended agricultural soils (0.405 to $1 \mathrm{~kg} \mathrm{~N}{ }_{2} \mathrm{O}-\mathrm{N} \mathrm{ha}^{-1}$; Granli and Bøckman, 1994; Bouwman, 1996; Mosier et al., 1996; Helgason et al., 2005) and within the documented range for managed boreal forest soils (0.1 to $0.6 \mathrm{~kg} \mathrm{~N}_{2} \mathrm{O}-\mathrm{N} \mathrm{ha}^{-1}$; Eggleston et al., 2006). Cumulative emissions during the second season were even lower (0.0576 to $0.231 \mathrm{~kg} \mathrm{~N}_{2} \mathrm{O}-\mathrm{N} \mathrm{ha}^{-1}$ ), suggesting low anthropogenic $\mathrm{N}_{2} \mathrm{O}$ emissions from the nonacidic mine tailings site where endemic forest floor (topsoil) was mixed prior to reforestation. 
Table 5. Mean cumulative ( $\pm \mathrm{SD}, n=3$ ) area-based $\mathrm{CO}_{2}$ emissions and induced emission factors (IEF) after the applications of landfilled paper mill sludge (LPMS) combined with a seeding of white clover (Trifolium repens) on two experimental sites (S1 and S2) and during two snow-free seasons (Years 1 and 2, LPMS applied in Year 1) on nonacidic mine tailings.

\begin{tabular}{|c|c|c|c|c|c|c|}
\hline \multirow{2}{*}{ Site } & \multirow{2}{*}{ Clover } & \multirow{2}{*}{$\begin{array}{l}\text { LPMS application } \\
\text { rate }\end{array}$} & \multicolumn{2}{|c|}{ Year 1} & \multicolumn{2}{|c|}{ Year 2} \\
\hline & & & Area-based $\mathrm{CO}_{2}$ emissions & LPMS-IEF & Area-based $\mathrm{CO}_{2}$ emissions & LPMS-IEF \\
\hline & & Mg dry LPMS ha-1 & $\mathrm{kg} \mathrm{CO}_{2}-\mathrm{Cha}^{-1}$ & $\mathrm{~kg} \mathrm{CO}_{2}-\mathrm{C} \mathrm{kg}^{-1} \mathrm{C}$ & $\mathrm{kg} \mathrm{CO}_{2}-\mathrm{Cha}^{-1}$ & $\mathrm{~kg} \mathrm{CO}_{2}-\mathrm{C} \mathrm{kg}^{-1} \mathrm{C}$ \\
\hline \multirow[t]{6}{*}{1} & Absence & 0 & $3,481 \pm 355$ & - & $5,271 \pm 1,550$ & - \\
\hline & & 50 & $6,741 \pm 858$ & $0.197 \pm 0.045$ & $9,768 \pm 758$ & $0.272 \pm 0.089$ \\
\hline & & 100 & $8,834 \pm 1,536$ & $0.162 \pm 0.037$ & $11,173 \pm 2,035$ & $0.179 \pm 0.027$ \\
\hline & Presence & 0 & $3,737 \pm 226$ & - & $6,149 \pm 2,213$ & - \\
\hline & & 50 & $5,784 \pm 612$ & $0.124 \pm 0.024$ & $8,075 \pm 1,420$ & $0.117 \pm 0.160$ \\
\hline & & 100 & $7,362 \pm 280$ & $0.110 \pm 0.012$ & $8,510 \pm 1,040$ & $0.0715 \pm 0.0422$ \\
\hline \multirow[t]{6}{*}{2} & Absence & 0 & $7,635 \pm 900$ & - & $7,537 \pm 750$ & - \\
\hline & & 50 & $8,383 \pm 593$ & $0.0787 \pm 0.152$ & $9,227 \pm 335$ & $0.178 \pm 0.096$ \\
\hline & & 100 & $9,313 \pm 1,195$ & $0.0882 \pm 0.110$ & $11,423 \pm 612$ & $0.204 \pm 0.072$ \\
\hline & Presence & 0 & $5,616 \pm 1,155$ & - & $6,895 \pm 1,417$ & - \\
\hline & & 50 & $7,726 \pm 1,301$ & $0.222 \pm 0.213$ & $8,951 \pm 1,042$ & $0.216 \pm 0.251$ \\
\hline & & 100 & $9,700 \pm 927$ & $0.215 \pm 0.099$ & $10,301 \pm 2,541$ & $0.179 \pm 0.115$ \\
\hline
\end{tabular}
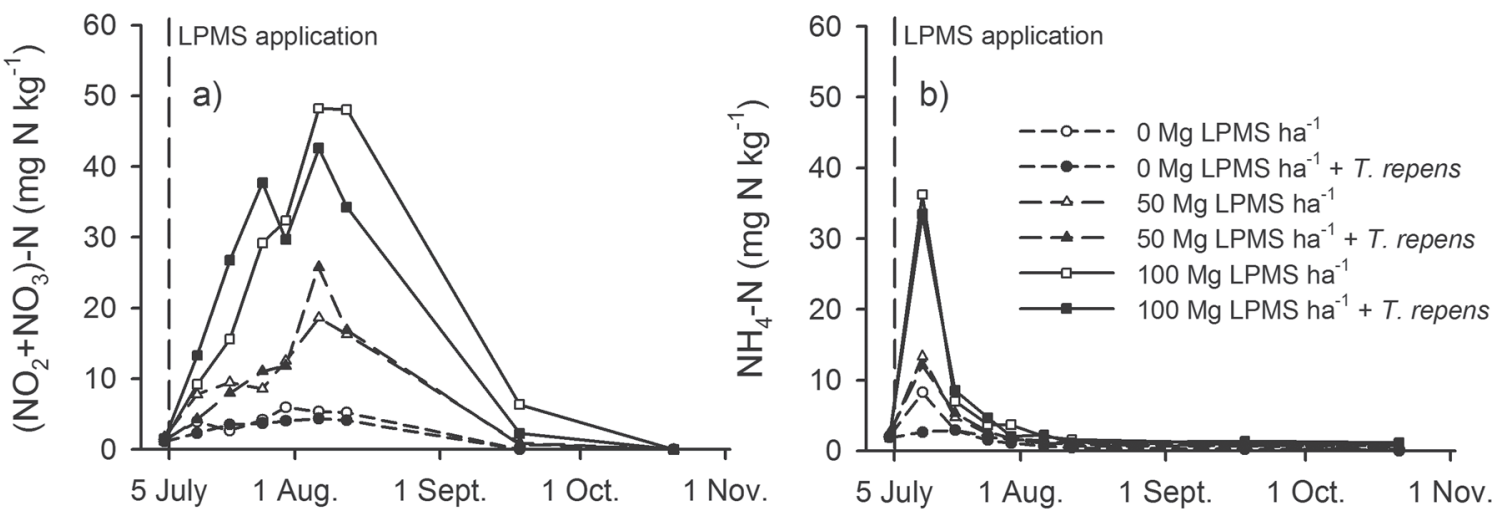

Fig. 2. Mean soil (a) $\mathrm{NO}_{2}+\mathrm{NO}_{3}$ and (b) $\mathrm{NH}_{4}$ concentrations after the applications of landfilled paper mill sludge (LPMS) combined with a seeding of white clover (Trifolium repens) on Site 2 during the first snow-free season of the experiment on nonacidic mine tailings. The LPMS application rates were of 0,50 , and $100 \mathrm{Mg}$ dry LPMS ha- ${ }^{-1}$, and seeding rates of white clover were of 0 and $12 \mathrm{~kg} \mathrm{ha}^{-1}(n=3)$. Vertical dashed lines indicate LPMS application dates.

Table 6. Mean ( $\pm \mathrm{SD}, \boldsymbol{n}=3$ ) soil $\mathrm{NO}_{2}+\mathrm{NO}_{3}$ and $\mathrm{NH}_{4}$ exposures after the applications of landfilled paper mill sludge (LPMS) combined with a seeding of white clover (Trifolium repens) on Site 2 during the first snow-free season of the experiment on nonacidic mine tailings. The $P$ values of the ANOVA testing the treatment effects are presented with the linear (Lin) and quadratic (Quad) contrasts performed when the fixed factors and their interactions resulted in significant differences between the treatments. Differences were considered statistically significant at $P<0.05$.

\begin{tabular}{lccc}
\hline Clover & $\begin{array}{c}\text { LPMS application } \\
\text { rate }\end{array}$ & $\mathrm{NO}_{2}+\mathrm{NO}_{3}$ exposure & $\mathrm{NH}_{4}$ exposure \\
\hline \multirow{4}{*}{ Absence } & Mg dry LPMS ha-1 & $\mathrm{g}_{\left(\mathrm{NO}_{2}+\mathrm{NO}_{3}\right)-\mathrm{N} \mathrm{d} \mathrm{kg}^{-1}}$ & $\mathrm{~g} \mathrm{NH}_{4}-\mathrm{N} \mathrm{d} \mathrm{kg}^{-1}$ \\
& 0 & $0.258 \pm 0.014$ & $0.157 \pm 0.075$ \\
Presence & 50 & $0.755 \pm 0.403$ & $0.217 \pm 0.117$ \\
& 100 & $2.12 \pm 0.42$ & $0.456 \pm 0.174$ \\
& 0 & $0.207 \pm 0.123$ & $0.085 \pm 0.035$ \\
& 50 & $0.781 \pm 0.331$ & $0.229 \pm 0.051$ \\
& 100 & $1.78 \pm 0.39$ & $0.447 \pm 0.11$ \\
\cline { 2 - 4 } & Source & ANOVA & \multicolumn{2}{c}{$P$ values } \\
\cline { 2 - 4 } \cline { 3 - 3 } & LPMS & $<0.0001$ & 0.0015 \\
& Lin & $<0.0001$ & 0.0005 \\
Quad & 0.0301 & 0.2904 \\
& Clover & 0.3443 & 0.6744 \\
& LPMS $\times$ clover & 0.4658 & 0.8048 \\
\hline
\end{tabular}

To the best of our knowledge, this is one of the first studies reporting $\mathrm{N}_{2} \mathrm{O}$ emissions from LPMS application for the reclamation of mine tailings (Larney and Angers, 2012; Faubert et al., 2016). In this context, comparisons of the trends observed in the $\mathrm{N}_{2} \mathrm{O}$ emissions can only be made with studies reporting the effect of organic amendments applied on agricultural soils, the type of soil for which most of this kind of knowledge exists.

Delays of 6 to $7 \mathrm{~d}$ between LPMS application and $\mathrm{N}_{2} \mathrm{O}$ peak fluxes were observed. Similar delays have been observed by Chadwick et al. (2000) and Chantigny et al. (2001) with farm animal manures applied on agricultural soils, but other studies have reported much shorter periods (e.g., 18 to $24 \mathrm{~h}$; Rochette et al., 2000a, 2004). Delays between LPMS application and soil $\left(\mathrm{NO}_{2}+\mathrm{NO}_{3}\right)-\mathrm{N}$ and $\mathrm{NH}_{4}-\mathrm{N}$ peak concentrations were also observed. The delays for $\mathrm{N}_{2} \mathrm{O}$ peak fluxes were likely influenced by $\mathrm{NO}_{3}$ availability through denitrification, which gradually increased after LPMS application (Burton et al., 2008; Thangarajan et al., 2013). The $\mathrm{N}_{2} \mathrm{O}$ peak fluxes were short lived and declined progressively to reach near-background levels after $40 \mathrm{~d}$. This duration is in agreement with periods ranging from 40 to $55 \mathrm{~d}$ for mixed primary and secondary PMS applied on agricultural clayey soils cropped to corn (Zea mays L.; Chantigny et al., 2013) and less than $60 \mathrm{~d}$ in manure-amended soils (Rochette 
et al., 2008a). These results suggest that most of the LPMSinduced $\mathrm{N}_{2} \mathrm{O}$ fluxes likely occur within the first $60 \mathrm{~d}$ after LPMS application, which may have been controlled by soil $\mathrm{NO}_{2}+\mathrm{NO}_{3}$ and $\mathrm{NH}_{4}$ availabilities through denitrification and nitrification (Thangarajan et al., 2013).

Nitrous oxide is produced in soils mostly as a byproduct of nitrification and an intermediate of denitrification (Davidson et al., 1986; Thangarajan et al., 2013). Soil water content is known to influence $\mathrm{N}_{2} \mathrm{O}$ emissions through its effect on microbial activity and $\mathrm{O}_{2}$ availability (Knowles, 1982). In this study, soil moisture content was correlated with $\mathrm{N}_{2} \mathrm{O}$ fluxes during the first season on S1, but no correlation was observed on S2. Interestingly, $\mathrm{N}_{2} \mathrm{O}$ peak fluxes on $\mathrm{S} 1$ were associated with higher soil moisture and rainfall events, especially during the week after LPMS application, whereas no such correlations were observed on S2. Rainfall events during the first season on S2 occurred once $\mathrm{N}_{2} \mathrm{O}$ fluxes had declined to near-background levels, which may partly explain the lack of correlation with soil moisture. These results indicate that soil moisture content does not conclusively explain soil-surface $\mathrm{N}_{2} \mathrm{O}$ fluxes in this study, probably caused by different meteorological conditions on both sites for which the LPMS application (i.e., first season of measurements) were done in different years. Other studies documented a significant relationship of this variable (expressed as water-filled pore space) with $\mathrm{N}_{2} \mathrm{O}$ fluxes after PMS or manure application on agricultural soils (Rochette et al., 2008a; Chantigny et al., 2010, 2013; Smith and Owens, 2010; Pelster et al., 2012), although Jarecki et al. (2008) did not observe a strong relationship between soil water content and $\mathrm{N}_{2} \mathrm{O}$ flux levels in either sandy or clayey soils.

Easily oxidizable $\mathrm{C}$ and mineral $\mathrm{N}$ availability have been documented to influence $\mathrm{N}_{2} \mathrm{O}$ emissions through nitrification and denitrification, both in laboratory (Azam et al., 2002) and field experiments (Petersen et al., 2008; Rochette et al., 2008a). Anoxic conditions prevailing in PMS disposal sites create suitable conditions for the production of $\mathrm{NH}_{4}$ and easily biodegradable $\mathrm{C}$ compounds such as volatile fatty acids, alcohols, and phenols (Spoelstra, 1979). This phenomenon has been documented for several organic amendments, such as pig and cattle slurries (Kirchmann and Lundvall, 1993) and poultry manure (Kirchmann and Witter, 1989), and for organic marine sediments (Valdemarsen and Kristensen, 2010). Easily oxidizable $\mathrm{C}$ compounds are rapidly used by soil microorganisms in aerobic conditions (Paul and Beauchamp, 1989; Chantigny et al., 2004). This is consistent with $\mathrm{N}_{2} \mathrm{O}$ and $\mathrm{CO}_{2}$ peak fluxes in the days after LPMS application on both sites, since respiration rate is indicative of soil available $\mathrm{C}$ levels and low soil $\mathrm{O}_{2}$ concentration, thereby favoring $\mathrm{N}_{2} \mathrm{O}$ emissions through denitrification (Rochette et al., 2000a; van Groenigen et al., 2005; Thangarajan et al., 2013).

Soil $\mathrm{NH}_{4}$ availability promotes microbial activity, which may stimulate $\mathrm{O}_{2}$ consumption and maintain anaerobic conditions at the microsite levels, in turn favoring denitrification (Azam et al., 2002), even under apparent aerobic conditions (Beauchamp et al., 1989). Also, $\mathrm{N}_{2} \mathrm{O}$ emissions have been documented to be correlated with soluble organic $\mathrm{C}$ availability in coarse-textured soils (Petersen et al., 2008; Chantigny et al., 2010), likely through increased heterotrophic respiration and denitrifier activity (Azam et al., 2002). The $\mathrm{N}_{2} \mathrm{O}$ emissions showed a positive relationship with soil $\mathrm{NO}_{2}+\mathrm{NO}_{3}$ exposure during the first season after LPMS application on S2; soil $\mathrm{NO}_{2}+\mathrm{NO}_{3}$ exposure was also increased by LPMS application. These observations suggest that denitrification played a role in $\mathrm{N}_{2} \mathrm{O}$ production in this study and was limited by labile $\mathrm{C}$ and $\mathrm{NO}_{3}$ availability (Azam et al., 2002; Rochette et al., 2004, 2008a; Burton et al., 2008). Moreover, the rapid increase and subsequent decrease in $\mathrm{CO}_{2}$ fluxes after LPMS application observed during the first season on $\mathrm{S} 1$ suggest that easily oxidizable $\mathrm{C}$ was rapidly metabolized by soil microbes, leaving recalcitrant $\mathrm{C}$ material such as lignin and cellulose (Camberato et al., 2006) and limited available C for denitrification.

The observed $\mathrm{N}_{2} \mathrm{O}$ peaks on $\mathrm{S} 2$ were followed by a rapid increase and subsequent decrease in $\mathrm{NH}_{4}$ availability during the first $3 \mathrm{wk}$ after application, with a peak reached after $1 \mathrm{wk}$. The $\mathrm{N}_{2} \mathrm{O}$ emissions were also positively correlated with soil $\mathrm{NH}_{4}$ exposure, which was also increased by LPMS application. These results suggest that nitrification may have induced $\mathrm{N}_{2} \mathrm{O}$ emissions. This is in agreement with field assays reporting complete nitrification of $\mathrm{NH}_{4}$ within 10 to $30 \mathrm{~d}$ after pig slurry application on agricultural soils (Chantigny et al., 2001, 2010; Rochette et al., 2004). In laboratory assays led by Stevens et al. (1997), denitrification was the dominant process at the beginning of the incubation, whereas nitrification was more important for the remainder of the experiment, contributing $70 \%$ of the overall $\mathrm{N}_{2} \mathrm{O}$ fluxes, regardless of soil moisture content. Nitrification was also documented to continue longer than observed $\mathrm{N}_{2} \mathrm{O}$ fluxes (Mulvaney et al., 1997; Williams et al., 1998), which is coherent with the observed late $\mathrm{NO}_{2}+\mathrm{NO}_{3}$ soil buildup observed in our experiment.

\section{Soil-Surface $\mathrm{CO}_{2}$ Emissions}

Soil-surface $\mathrm{CO}_{2}$ fluxes have been documented as a good indicator of organic amendment decomposition and $\mathrm{C}$ mineralization rates (Rochette et al., 2006). Soil-surface $\mathrm{CO}_{2}$ fluxes were coherent with the two phases of organic amendment decomposition generally observed (i.e., rapid decomposition followed by slow and long-term decomposition; Fierro et al., 2000; Camberato et al., 2006). High rates of $C$ mineralization immediately after organic amendment application are well known for liquid manures, which are rich in volatile organic compounds (Rochette et al., 2004). The cumulative area-based $\mathrm{CO}_{2}$ emissions were significantly increased by LPMS application. This result is consistent with increased $\mathrm{CO}_{2}$ emissions from poultry litter application combined with cultivation of Brachiaria brizantha (Hochst. ex A. Rich.) Stapf in a bauxite-mined area under reclamation (Oliveira et al., 2017).

\section{$\mathrm{N}_{2} \mathrm{O}$ and $\mathrm{CO}_{2}$ Emission Factors}

The average LPMS-IEF values for $\mathrm{N}_{2} \mathrm{O}$ emissions of 1.04 to $2.43 \%$ of total applied $\mathrm{N}$ during the first season on both sites were higher than the averages of 0.9 and $1 \%$ reported for land application of mixed PMS on clayey soils (Chantigny et al., 2013; Faubert et al., 2015). The LPMS-IEFs measured in the present study were also higher than the mean weighted induced emission factor of $0.02 \%$ reported in a meta-analysis on organic amendments applied to agricultural soils, for which PMS was classified in the low-risk group (Charles et al., 2017). On the other hand, an emission factor as high as 5\% was reported for PMS application on a soil that had been cropped with calabrese (Brassica oleracea italica var. cymosa; Baggs et al., 2002). No emission factor 
has been reported so far for LPMS application on reclaimed land (Larney and Angers, 2012; Faubert et al., 2016). The LPMS-IEF values obtained were generally higher than the IPCC default value of $1 \%$, although within the range of 0.3 to $3 \%$ for mineral and organic $\mathrm{N}$ applications on agricultural lands (Eggleston et al., 2006). The LPMS-IEF values reported here are consistent with other studies in Eastern Canada documenting $\mathrm{N}_{2} \mathrm{O}$ emissions from organic fertilizers (animal slurries and manures) applied on coarse-textured soils, with IEFs ranging between 0.2 and 2.73\% (Rochette et al., 2000b, 2004; Gregorich et al., 2005; Chantigny et al., 2010; Pelster et al., 2012). Differences between emission factors are caused by multiple variables such as soil preparation, texture, and chemical characteristics; source of applied N (mineral vs. organic); and climatic conditions (Rochette et al., 2008b; Thangarajan et al., 2013).

The LPMS-IEFs for $\mathrm{CO}_{2}$ emissions were between 8 and 22\% of total applied C after the first season and 7 to $27 \%$ after the second season. These values are much lower than the emission factors reported from land application of animal slurries and manures on agricultural soils ranging between 42 and 105\% (Bernal and Kirchmann, 1992; Kirchmann and Lundvall, 1993; Gregorich et al., 1998; Rochette et al., 2004). This is probably due to the higher content of recalcitrant $\mathrm{C}$ such as cellulose and lignin in LPMS compared with animal manures (Camberato et al., 2006). Our results are also consistent with results from previous studies reporting that $40 \%$ of deinking PMS remained in the soil $2 \mathrm{yr}$ after application (Chantigny et al., 1999).

\section{Implications for Land Reclamation of Nonacidic Mine Tailings Sites}

The LPMS-IEFs reported here for $\mathrm{N}_{2} \mathrm{O}$ and $\mathrm{CO}_{2}$ emissions were generally similar to or lower than the emission factors measured for land application of PMS, animal slurries, and manures on agricultural soils. In a life-cycle perspective, the direct GHG emissions from land application of LPMS for mine tailings reclamation could be offset through various ways. The LPMS used as amendments on mine tailings could decrease global GHG emissions as compared with the use of mineral $\mathrm{N}$ fertilizers, for which the $\mathrm{C}$ footprint of production is between 0.4 and $13.4 \mathrm{~kg} \mathrm{CO}$ eq. $\mathrm{kg}^{-1} \mathrm{~N}$ (Wood and Cowie, 2004; Brown et al., 2010). Land reclamation of mine tailings with LPMS amendments would provide ecosystem-regulating services through $\mathrm{C}$ storage and sequestration and climate regulation (Larney and Angers, 2012). The C-poor mine tailings (Table 1) have a great potential to store $\mathrm{C}$ through the input of organic matter enhanced by LPMS application (Shipitalo and Bonta, 2008; Larney and Angers, 2012) or other types of organic amendments (Shrestha and Lal, 2006; Shrestha et al., 2009; Torri et al., 2014; del Mar Montiel-Rozas et al., 2016). Part of the C applied with LPMS could be stocked in the tailings, as reported for deinking PMS on agricultural soils (Chantigny et al., 1999). Input of organic matter through fallen litter and roots from perennial vegetation, such as the white clover used in this study, and trees could increase the tailings $C$ stock (Shrestha et al., 2009; Frouz, 2017; Gregorich et al., 2017; Oliveira et al., 2017). Tree plantations on reclaimed mine tailings could benefit from fertilization with LPMS amendment, as reported in silviculture (Jackson et al., 2000). Increased net primary productivity through plant growth on reclaimed mine tailings could increase $\mathrm{C}$ sequestration
(Lal, 2003; Shipitalo and Bonta, 2008; Larney and Angers, 2012; Oliveira et al., 2017), which could offset GHG emissions from reclamation operations and mine industrial processes (Shrestha and Lal, 2006; Boucher et al., 2012). This still needs further investigation before making general assumptions.

The application of LPMS for land reclamation of mine tailings could enhance the industrial symbioses in which the residue of one industry becomes a resource for another industry (Faubert et al., 2016). In the present case study, PMS from the landfill site of a pulp and paper mill benefitted a mine company located in the same region through tailings reclamation. Such industrial symbioses could be a sustainable solution to meet the objectives of certain jurisdictions that tend to reduce or ban landfilling of PMS (Faubert et al., 2016), as slated by 2020 in the province of Quebec (MDDEP, 2011; Gouvernement du Québec, 2012). In this jurisdiction, there is also a high potential for using LPMS for mine land reclamation as an alternative to landfilling, with a territory of $>12,000$ ha that needs to be restored or is in the restoration process (MERN, 2017). This practice should also be examined for its potential to generate $\mathrm{C}$-offset credits that could be traded on the voluntary $\mathrm{C}$ market, as well as on the regulated $\mathrm{C}$ market (e.g., the Western Climate Initiative in North America). Therefore, further research should concentrate on quantifying the direct GHG emissions from PMS landfilling, the businessas-usual scenario, compared with the alternative scenario of LPMS application for mine tailings reclamation, using life-cycle analyses (Faubert et al., 2016). In this context, other studies are also needed on the GHG emissions from LPMS application to reduce the uncertainty of the emission factors in a variety of mine tailings, reclamation scenarios, and climatic conditions.

\section{Conclusion}

This study provided field-measured emission factors for LPMS that could be helpful in reducing the uncertainties related to the GHG emissions after land application of this soil amendment on reclaimed lands. Our results show that LPMS application on a nonacidic mine tailings site during two consecutive snow-free seasons increased soil $\mathrm{N}_{2} \mathrm{O}$ emissions compared with the unamended control during the first season of application, whereas the increase of $\mathrm{CO}_{2}$ emissions lasted over both seasons. The $\mathrm{CH}_{4}$ fluxes after LPMS application were negligible; a slight oxidation occurred on this well-drained site. The perennial white clover used for tailings reclamation did not affect soil GHG emissions. These results indicate that GHG emissions from this practice should be considered in life-cycle analyses evaluating the $\mathrm{C}$ footprint of industrial symbioses between the mine and pulp and paper industries, as well as by governmental authorities in their policies on PMS management practices and mine tailings reclamation. Future research should be pursued to assess the effect of LPMS and PMS applications on soil GHG emissions from a variety of mine tailings under a wide array of management and climatic conditions to plan responsible and sustainable land reclamation.

\section{Acknowledgments}

The study was financially supported by Niobec, Chaire en éco-conseil (Université du Québec à Chicoutimi) and Programme Carbone boréal (Université du Québec à Chicoutimi). A research fellowship from the Mitacs Elevate program was awarded to Patrick Faubert. Research fellowships from the Fonds québécois de Recherche sur la Nature et les Technologies and RECYC-QUÉBEC were awarded to Simon 
Durocher. We thank the operational partners of this study: Niobec and Resolute Forest Products-Kénogami Mill. We are also thankful to Olivier Fradette, Frédéric Gagnon, and Stéphanie Girard for the data collection on the field, as well as to Catherine Lemay-Bélisle for her contribution to data collection and analysis. We finally thank Denis Walsh for his input on the statistical analyses, Martin Chantigny for comments provided on this work, and anonymous reviewers for their very helpful comments.

\section{References}

Azam, F., C. Müller, A. Weiske, G. Benckiser, and J. Ottow. 2002. Nitrification and denitrification as sources of atmospheric nitrous oxide- role of oxidizable carbon and applied nitrogen. Biol. Fertil. Soils 35:54-61. doi:10.1007/s00374-001-0441-5

Baggs, E.M., R.M. Rees, K. Castle, A. Scott, K.A. Smith, and A.J.A. Vinten. 2002. Nitrous oxide release from soils receiving $\mathrm{N}$-rich crop residues and paper mill sludge in eastern Scotland. Agric. Ecosyst. Environ. 90:109123. doi:10.1016/S0167-8809(01)00175-X

Beauchamp, E.G., J.T. Trevors, and J.W. Paul. 1989. Carbon sources for bacterial denitrification. In: B.A. Stewart, editor, Advances in soil science. Springer, New York. p. 113-142. doi:10.1007/978-1-4613-8847-0_3

Bernal, M.P., and H. Kirchmann. 1992. Carbon and nitrogen mineralization and ammonia volatilization from fresh, aerobically and anaerobically treated pig manure during incubation with soil. Biol. Fertil. Soils 13:135-141. doi: $10.1007 /$ BF00336268

Boeckx, P., and O. Van Cleemput. 1996. Flux estimates from soil methanogenesis and methanotrophy: Landfills, rice paddies, natural wetlands and aerobic soils. Environ. Monit. Assess. 42:189-207. doi:10.1007/BF00394050

Boucher, J.F., P. Tremblay, S. Gaboury, and C. Villeneuve. 2012. Can boreal afforestation help offset incompressible GHG emissions from Canadian industries? Process Saf. Environ. Prot. 90:459-466. doi:10.1016/j. psep.2012.10.011

Bouwman, A.F. 1996. Direct emission of nitrous oxide from agricultural soils. Nutr. Cycling Agroecosyst. 46:53-70. doi:10.1007/BF00210224

Bouwman, A.F., L.J.M. Boumans and N.H. Batjes. 2002. Emissions of $\mathrm{N}_{2} \mathrm{O}$ and NO from fertilized fields: Summary of available measurement data. Global Biogeochem. Cycles 16:6-1-6-13. doi:10.1029/2001gb001811

Brown, S., N. Beecher, and A. Carpenter. 2010. Calculator tool for determining greenhouse gas emissions for biosolids processing and end use. Environ. Sci. Technol. 44:9509-9515. doi:10.1021/es101210k

Burton, D.L., B.J. Zebarth, K.M. Gillam, and J.A. MacLeod. 2008. Effect of split application of fertilizer nitrogen on $\mathrm{N}_{2} \mathrm{O}$ emissions from potatoes. Can. J. Soil Sci. 88:229-239. doi:10.4141/CJSS06007

Camberato, J.J., B. Gagnon, D.A. Angers, M.H. Chantigny, and W.L. Pan. 2006. Pulp and paper mill by-products as soil amendments and plant nutrient sources. Can. J. Soil Sci. 86:641-653. doi:10.4141/S05-120

Chadwick, D.R., B.F. Pain, and S.K.E. Brookman. 2000. Nitrous oxide and methane emissions following application of animal manures to grassland. J. Environ. Qual. 29:277-287. doi:10.2134/jeq2000.00472425002900010035x

Chantigny, M.H., D.A. Angers, and C.J. Beauchamp. 1999. Aggregation and organic matter decomposition in soils amended with de-inking paper sludge. Soil Sci. Soc. Am. J. 63:1214-1221. doi:10.2136/sssaj1999.6351214x

Chantigny, M.H., D.A. Angers, and C.J. Beauchamp. 2000. Active carbon pools and enzyme activities in soils amended with de-inking paper sludge. Can. J. Soil Sci. 80:99-105. doi:10.4141/S99-050

Chantigny, M.H., D.E. Pelster, M.-H. Perron, P. Rochette, D.A. Angers, L.-É. Parent, D. Massé, and N. Ziadi. 2013. Nitrous oxide emissions from clayey soils amended with paper sludges and biosolids of separated pig slurry. J. Environ. Qual. 42:30-39. doi:10.2134/jeq2012.0196

Chantigny, M.H., P. Rochette, and D.A. Angers. 2001. Short-term C and N dynamics in a soil amended with pig slurry and barley straw: A field experiment. Can. J. Soil Sci. 81:131-137. doi:10.4141/S00-046

Chantigny, M.H., P. Rochette, D.A. Angers, S. Bittman, K. Buckley, D. Massé et al. 2010. Soil nitrous oxide emissions following band-incorporation of fertilizer nitrogen and swine manure. J. Environ. Qual. 39:1545-1553. doi:10.2134/jeq2009.0482

Chantigny, M.H., P. Rochette, D.A. Angers, D. Massé, and D. Côté. 2004. Ammonia volatilization and selected soil characteristics following application of anaerobically digested pig slurry. Soil Sci. Soc. Am. J. 68:306-312. doi:10.2136/sssaj2004.3060

Charles, A., P. Rochette, J.K. Whalen, D.A. Angers, M.H. Chantigny, and N. Bertrand. 2017. Global nitrous oxide emission factors from agricultural soils after addition of organic amendments: A meta-analysis. Agric. Ecosyst. Environ. 236:88-98. doi:10.1016/j.agee.2016.11.021
Dambreville, C., S. Hallet, C. Nguyen, T. Morvan, J.-C. Germon, and L. Philippot. 2006a. Structure and activity of the denitrifying community in a maize-cropped field fertilized with composted pig manure or ammonium nitrate. FEMS Microbiol. Ecol. 56:119-131. doi:10.1111/j.1574-6941.2006.00064.x

Dambreville, C., C. Hénault, F. Bizouard, T. Morvan, R. Chaussod, and J.-C. Germon. 2006b. Compared effects of long-term pig slurry applications and mineral fertilization on soil denitrification and its end products $\left(\mathrm{N}_{2} \mathrm{O}, \mathrm{N}_{2}\right)$. Biol. Fertil. Soils 42:490-500. doi:10.1007/ s00374-005-0040-y

Davidson, E.A., W.T. Swank, and T.O. Perry. 1986. Distinguishing between nitrification and denitrification as sources of gaseous nitrogen production in soil. Appl. Environ. Microbiol. 52:1280-1286.

de Klein, C.A.M., and M.J. Harvey. 2015. Nitrous oxide chamber methodology guidelines. Version 1.1. Global Res. Alliance on Agric. Greenhouse Gases, Wellington, New Zealand.

del Mar Montiel-Rozas, M., M. Panettieri, P. Madejón, and E. Madejón. 2016. Carbon sequestration in restored soils by applying organic amendments. Land Degrad. Dev. 27:620-629. doi:10.1002/ldr.2466

Eggleston, H.S., L. Buendia, K. Miwa, T. Ngara, and K. Tanabe, editors. 2006. 2006 IPCC guidelines for national greenhouse gas inventories, prepared by the National Greenhouse Gas Inventories Programme. Inst. Global Environ. Strat., Hayama, Kanagawa, Japan.

Faubert, P., S. Barnabé, S. Bouchard, R. Côté, and C. Villeneuve. 2016. Pulp and paper mill sludge management practices: What are the challenges to assess the impacts on greenhouse gas emissions? Resour. Conserv. Recycl. 108:107-133. doi:10.1016/j.resconrec.2016.01.007

Faubert, P., C. Lemay-Bélisle, N. Bertrand, S. Bouchard, M. Chantigny, S. Durocher et al. 2015. Pulp and paper mill sludge management in Quebec: What should be the best option to reduce greenhouse gas emissions? (In French, with English abstract.) Vecteur Environ. 48:50-58.

Fierro, A., D.A. Angers, and C.J. Beauchamp. 1999. Restoration of ecosystem function in an abandoned sandpit: Plant and soil responses to paper de-inking sludge. J. Appl. Ecol.36:244-253. doi:10.1046/j.1365-2664.1999.00395.x

Fierro, A., D.A. Angers, and C.J. Beauchamp. 2000. Decomposition of paper de-inking sludge in a sandpit minesoil during its revegetation. Soil Biol. Biochem. 32:143-150. doi:10.1016/S0038-0717(99)00123-6

Frouz, J. 2017. Effects of soil development time and litter quality on soil carbon sequestration: Assessing soil carbon saturation with a field transplant experiment along a post-mining chronosequence. Land Degrad. Dev. 28:664-672. doi:10.1002/ldr.2580

Giroux, M., and P. Audesse. 2004. Comparison of two methods for the determination of organic carbon, total nitrogen and $\mathrm{C} / \mathrm{N}$ ratio of different organic amendments and manures. (In French, with English abstract.) Agrosol 15:107-110.

Gouvernement du Québec. 2012. Québec in action greener by 2020. 2013-2020 climate change action plan. Phase 1. Gouvernement du Québec, Quebec City, QC, Canada.

Granli, T., and O.C. Bøckman. 1994. Nitrous oxide from agriculture. Nor. J. Agric. Sci. Suppl. 12:1-128.

Gregorich, E.G., H. Janzen, B.H. Ellert, B.L. Helgason, B. Qian, B.J. Zebarth et al. 2017. Litter decay controlled by temperature, not soil properties, affecting future soil carbon. Glob. Change Biol. 23:1725-1734. doi:10.1111/ gcb. 13502

Gregorich, E.G., P. Rochette, S. McGuire, B.C. Liang, and R. Lessard. 1998. Soluble organic carbon and carbon dioxide fluxes in maize fields receiving spring-applied manure. J. Environ. Qual. 27:209-214. doi:10.2134/ jeq1998.00472425002700010029x

Gregorich, E.G., P. Rochette, A.J. VandenBygaart, and D.A. Angers. 2005. Greenhouse gas contributions of agricultural soils and potential mitigation practices in eastern Canada. Soil Tillage Res. 83:53-72. doi:10.1016/j. still.2005.02.009

Hansen, S., J.E. Mæhlum, and L.R. Bakken. 1993. $\mathrm{N}_{2} \mathrm{O}$ and $\mathrm{CH}_{4}$ fluxes in soil influenced by fertilization and tractor traffic. Soil Biol. Biochem. 25:621630. doi:10.1016/0038-0717(93)90202-M

Helgason, B.L., H.H. Janzen, M.H. Chantigny, C.F. Drury, B.H. Ellert, E.G. Gregorich et al. 2005. Toward improved coefficients for predicting direct $\mathrm{N}_{2} \mathrm{O}$ emissions from soil in Canadian agroecosystems. Nutr. Cycling Agroecosyst. 72:87-99. doi:10.1007/s10705-004-7358-y

IUSS Working Group (International Union of Soil Sciences Working Group). 2015. World reference base for soil resources 2014, update 2015. International soil classification system for naming soils and creating legends for soil maps. FAO, Rome, Italy.

Jackson, M.J., M.A. Line, S. Wilson, and S.J. Hetherington. 2000. Application of composted pulp and paper mill sludge to a young pine plantation. J. Environ. Qual. 29:407-414. doi:10.2134/jeq2000.00472425002900020006x 
Jarecki, M.K., T.B. Parkin, A.S.K. Chan, J.L. Hatfield, and R. Jones. 2008. Greenhouse gas emissions from two soils receiving nitrogen fertilizer and swine manure slurry. J. Environ. Qual. 37:1432-1438. doi:10.2134/ jeq2007.0427

Kirchmann, H., and A. Lundvall. 1993. Relationship between N immobilization and volatile fatty acids in soil after application of pig and cattle slurry. Biol. Fertil. Soils 15:161-164. doi:10.1007/BF00361605

Kirchmann, H., and E. Witter. 1989. Ammonia volatilization during aerobic and anaerobic manure decomposition. Plant Soil 115:35-41. doi:10.1007/ BF02220692

Knowles, R. 1982. Denitrification. Microbiol. Rev. 46:43-70.

Lal, R. 2003. Offsetting global $\mathrm{CO}_{2}$ emissions by restoration of degraded soils and intensification of world agriculture and forestry. Land Degrad. Dev. 14:309-322. doi: 10.1002/ldr.562

Larney, F.J., and D.A. Angers. 2012. The role of organic amendments in soil reclamation: A review. Can. J. Soil Sci. 92:19-38. doi:10.4141/cjss2010-064

Le Mer, J., and P. Roger. 2001. Production, oxidation, emission and consumption of methane by soils: A review. Eur. J. Soil Biol. 37:25-50. doi:10.1016/ S1164-5563(01)01067-6

Loro, P.J., D.W. Bergstrom, and E.G. Beauchamp. 1997. Intensity and duration of denitrification following application of manure and fertilizer to soil. J. Environ. Qual. 26:706-713. doi:10.2134/jeq1997.00472425002600030016x

Maynard, D.G., Y.P. Kalra, and J.A. Crumbaugh. 2008. Nitrate and exchangeable ammonium nitrogen. In: M.R. Carter and E.G. Gregorich, editors, Soil sampling and methods of analysis. CRC Press, Boca Raton, FL. p. 71-80.

MDDELCC (Ministère du Développement durable, de l'Environnement et de laLutte contre les changements climatiques). 2016. Bilan annuel de conformité environnementale 2013. Secteur des pâtes et papiers. (In French.) Gouvernement du Québec, Quebec City, QC, Canada.

MDDEP (Ministère du Développement durable, de l'Environnement et des Parcs). 2011. Québec residual materials management policy. (In French.) Gouvernement du Québec, Quebec City, QC, Canada.

MERN (Ministère de l'Énergie et des Ressources naturelles). 2017. Gestim plus. Gestion des titres miniers. (In French.) Gouvernement du Québec. https://gestim.mines.gouv.qc.ca/MRN_GestimP_Presentation/ ODM02101_login.aspx (accessed on 23 Feb. 2017).

Mogge, B., E.-A. Kaiser, and J.-C. Munch. 1999. Nitrous oxide emissions and denitrification N-losses from agricultural soils in the Bornhöved lake region: Influence of organic fertilizers and land-use. Soil Biol. Biochem. 31:12451252. doi:10.1016/S0038-0717(99)00039-5

Mosier, A.R., J.M. Duxbury, J.R. Freney, O. Heinemeyer, and K. Minami. 1996. Nitrous oxide emissions from agricultural fields: Assessment, measurement and mitigation. Plant Soil 181:95-108. doi:10.1007/BF00011296

Mulvaney, L.R., A.S. Khan, and S.C. Mulvaney. 1997. Nitrogen fertilizers promote denitrification. Biol. Fertil. Soils 24:211-220. doi:10.1007/ s003740050233

Oliveira, D.M.S., I.R.d. Silva, G.O. Mendes, A.A. Vasconcelos, G.C.V. Mayrink, and E.E.J. Verburg. 2017. Carbon fluxes from different pools in a mined area under reclamation in Minas Gerais State, Brazil. Land Degrad. Dev. 28:507-514. doi:10.1002/ldr.2601

Paul, J.W., and E.G. Beauchamp. 1989. Effect of carbon constituents in manure on denitrification in soil. Can. J. Soil Sci. 69:49-61. doi:10.4141/ cjss89-006

Pelster, D.E., M.H. Chantigny, P. Rochette, D.A. Angers, C. Rieux, and A. Vanasse. 2012. Nitrous oxide emissions respond differently to mineral and organic nitrogen sources in contrasting soil types. J. Environ. Qual. 41:427-435. doi: 10.2134/jeq2011.0261

Petersen, S., P. Schjonning, I. Thomsen, and B. Christensen. 2008. Nitrous oxide evolution from structurally intact soil as influenced by tillage and soil water content. Soil Biol. Biochem. 40:967-977. doi:10.1016/j. soilbio.2007.11.017

Piearce, T.G., T. Budd, J.M. Hayhoe, D. Sleep, and P.J. Clasper. 2003. Earthworms of a land restoration site treated with paper mill sludge: The 7th international symposium on earthworm ecology, Cardiff, Wales, 2002. Pedobiolgia 47:792-795. doi:10.1078/0031-4056-00260

Rochette, P., D.A. Angers, M.H. Chantigny, N. Bertrand, and D. Côté. 2004. Carbon dioxide and nitrous oxide emissions following fall and spring applications of pig slurry to an agricultural soil. Soil Sci. Soc. Am. J. 68:14101420. doi: $10.2136 /$ sssaj2004.1410

Rochette, P., D.A. Angers, M.H. Chantigny, B. Gagnon, and N. Bertrand. 2006. In situ mineralization of dairy cattle manures as determined using soil-surface carbon dioxide fluxes. Soil Sci. Soc. Am. J. 70:744-752. doi:10.2136/ sssaj2005.0242
Rochette, P., D.A. Angers, M.H. Chantigny, B. Gagnon, and N. Bertrand. 2008a. $\mathrm{N}_{2} \mathrm{O}$ fluxes in soils of contrasting textures fertilized with liquid and solid dairy cattle manures. Can. J. Soil Sci. 88:175-187. doi:10.4141/ CJSS06016

Rochette, P., D.A. Angers, and D. Côté. 2000a. Soil carbon and nitrogen dynamics following application of pig slurry for the 19th consecutive year I. Carbon dioxide fluxes and microbial biomass carbon. Soil Sci. Soc. Am. J. 64:1389-1395. doi:10.2136/sssaj2000.6441389x

Rochette, P., and N. Bertrand. 2008. Soil-surface gas emissions. In: M.R. Carter and E.G. Gregorich, editors, Soil sampling and methods of analysis. CRC Press, Boca Raton, FL. p. 851-861.

Rochette, P., E. van Bochove, D. Prévost, D.A. Angers, D. Côté, and N. Bertrand. 2000b. Soil carbon and nitrogen dynamics following application of pig slurry for the 19th consecutive year II. Nitrous oxide fluxes and mineral nitrogen. Soil Sci. Soc. Am. J. 64:1396-1403. doi:10.2136/ sssaj2000.6441396x

Rochette, P., D.E. Worth, R.L. Lemke, B.G. McConkey, D.J. Pennock, C. Wagner-Riddle, and R.J. Desjardins. 2008b. Estimation of $\mathrm{N}_{2} \mathrm{O}$ emissions from agricultural soils in Canada. I. Development of a country-specific methodology. Can. J. Soil Sci. 88:641-654. doi:10.4141/CJSS07025

Rutherford, P.M., W.B. McGill, C.T. Figueiredo, and J.M. Arocena. 2008. Total nitrogen. In: M. Carter and E.G. Gregorich, editors, Soil sampling and methods of analysis. CRC Press, Boca Raton, FL. p. 239-250.

SAS Institute. 2015. JMP Pro software. Release 12.0.1. SAS Inst., Cary, NC.

Sheppard, S.C., and J.A. Addison. 2008. Soil sample handling and storage. In: M.R. Carter and E.G. Gregorich, editors, Soil sampling and methods of analysis. CRC Press, Boca Raton, FL. p. 39-49.

Shipitalo, M.J., and J.V. Bonta. 2008. Impact of using paper mill sludge for surface-mine reclamation on runoff water quality and plant growth. J. Environ. Qual. 37:2351-2359. doi:10.2134/jeq2007.0648

Shrestha, R.K., and R. Lal. 2006. Ecosystem carbon budgeting and soil carbon sequestration in reclaimed mine soil. Environ. Int. 32:781-796. doi:10.1016/j.envint.2006.05.001

Shrestha, R.K., R. Lal, and P.-A. Jacinthe. 2009. Enhancing carbon and nitrogen sequestration in reclaimed soils through organic amendments and chiseling. Soil Sci. Soc. Am. J. 73:1004-1011. doi:10.2136/sssaj2008.0216

Skjemstad, J.O., and J.A. Baldock. 2008. Total and organic carbon. In: M.R. Carter and E.G. Gregorich, editors, Soil sampling and methods of analysis. CRC Press, Boca Raton, FL. p. 225-237.

Smith, D.R., and P.R. Owens. 2010. Impact of time to first rainfall event on greenhouse gas emissions following manure applications. Commun. Soil Sci. Plant Anal. 41:1604-1614. doi:10.1080/00103624.2010.485240

Spoelstra, S.F. 1979. Volatile fatty acids in anaerobically stored piggery wastes. Neth. J. Agric. Sci. 27:60-66.

Stevens, R.J., R.J. Laughlin, L.C. Burns, J.R.M. Arah, and R.C. Hood. 1997. Measuring the contributions of nitrification and denitrification to the flux of nitrous oxide from soil. Soil Biol. Biochem. 29:139-151. doi:10.1016/ S0038-0717(96)00303-3

Tenuta, M., D.W. Bergstrom, and E.G. Beauchamp. 2000. Denitrifying enzyme activity and carbon availability for denitrification following manure application. Commun. Soil Sci. Plant Anal. 31:861-876. doi: $10.1080 / 00103620009370483$

Thangarajan, R., N.S. Bolan, G. Tian, R. Naidu, and A. Kunhikrishnan. 2013. Role of organic amendment application on greenhouse gas emission from soil. Sci. Total Environ. 465:72-96. doi:10.1016/j.scitotenv.2013.01.031

Torri, S.I., R.S. Corrêa, and G. Renella. 2014. Soil carbon sequestration resulting from biosolids application. Appl. Environ. Soil Sci. 2014:821768. doi: $10.1155 / 2014 / 821768$

Valdemarsen, T., and E. Kristensen. 2010. Degradation of dissolved organic monomers and short-chain fatty acids in sandy marine sediment by fermentation and sulfate reduction. Geochim. Cosmochim. Acta 74:15931605. doi:10.1016/j.gca.2009.12.009

van Groenigen, J.W., P.J. Kuikman, W.J.M. de Groot, and G.L. Velthof. 2005. Nitrous oxide emission from urine-treated soil as influenced by urine composition and soil physical conditions. Soil Biol. Biochem. 37:463-473. doi:10.1016/j.soilbio.2004.08.009

Williams, P.H., S.C. Jarvis, and E. Dixon. 1998. Emission of nitric oxide and nitrous oxide from soil under field and laboratory conditions. Soil Biol. Biochem. 30:1885-1893. doi:10.1016/S0038-0717(98)00052-2

Wood, S. and C. Cowie. 2004. A review of greenhouse gas emission factors for fertiliser production. Task 38. IEA Bioenergy. 